\title{
cDNA cloning, expression and characterization of a Boophilus microplus paramyosin
}

\author{
C. A. S. FERREIRA ${ }^{1,5,6}$, M. C. BARBOSA ${ }^{1}$, T. C. L. SILVEIRA ${ }^{1}$, J. G. VALENZUELA ${ }^{4}$, \\ I. DA SILVA VAZ JR ${ }^{1,2,3}$ and A. MASUDA ${ }^{1,2 *}$ \\ ${ }^{1}$ Centro de Biotecnologia do Estado do Rio Grande do Sul, ${ }^{2}$ Departamento de Biologia Molecular e Biotecnologia, \\ ${ }^{3}$ Faculdade de Veterinária, UFRGS, Av. Bento Gonçalves 9500, Porto Alegre, RS, Brazil - C.P. 15005 - CEP \\ 91501-970 \\ ${ }^{4}$ Laboratory of Parasitic Diseases, National Institute of Allergy and Infectious Diseases, National Institutes of Health, 4 \\ Center Dr., Rm. 4/126, Bethesda, MD 20892, USA \\ ${ }^{5}$ Departamento de Ciências Microbiológicas, PUC-RS, Av. Ipiranga 6681, Porto Alegre, RS, Brazil-CEP $90619-900$ \\ ${ }^{6}$ Centro de Ciências da Saúde, UNISINOS, Av. Unisinos 950, São Leopoldo, RS, Brazil-CEP 93022-000
}

(Received 11 February 2002 ; revised 15 April 2002; accepted 15 April 2002)

SUMMARY

The tick Boophilus microplus is a 1-host tick that causes important losses to bovine herds, and protective antigens are being investigated in order to develop vaccines that avoid the use of acaricides. Paramyosins are multi-functional invertebrate muscle proteins, whose roles may include host immunomodulation, and seem to be a prominent candidate in a schistosomiasis vaccine. We report here the cloning, expression and characterization of a B. microplus paramyosin (BmPRM). Sequence analysis of the full length coding sequence cDNA shows high identity to other arthropod paramyosin sequences, and the predicted molecular weight, pI and secondary structure are consistent with a typical paramyosin. Western-blot expression analysis indicates the presence of BmPRM in all tissues and developmental stages tested, but not in saliva. The recombinant protein (rBmPRM) was shown to bind both IgG and collagen. Possible implications of these activities with host evasion mechanisms are discussed.

Key words: paramyosin, Boophilus microplus, IgG binding protein, collagen binding protein, tick.

\section{INTRODUCTION}

Ixodidae ticks are blood-sucking parasites that infest a wide array of mammals. Boophilus microplus is a 1host tick that causes major losses to bovine herds, especially in tropical regions. Major efforts have been expended to develop immunoprophylatic tools in order to achieve better control of the parasite, minimizing or eliminating the use of acaricides that raises costs and contaminates milk, meat and the environment (Nolan, 1985). Possible immunogens have been described (Mulenga, Sugimoto \& Onuma, 2000) and vaccines based on the concept of concealed antigens (Willadsen \& Kemp, 1988) are being commercialized (Willadsen et al. 1995 ; Rodriguez et al. 1995a). Unfortunately, the degree of protection achieved is not complete (Willadsen \& Kemp, 1988). The use of acaricides is still required in the best scenario, and field trials showed considerable variation among the different regions tested (Rodriguez et al. 1995 b), possibly resulting from polymorphisms of the antigens (Garcia-Garcia et al. 2000). The discovery of new protective antigens would be

* Corresponding author: Centro de Biotecnologia do Estado do Rio Grande do Sul, Campus do Vale, UFRGS Caixa Postal 15005-91501-970, Porto Alegre RS Brazil. Tel: + 55 (51) 33166078. Fax: + 55 (51) 33167309. Email: aoi@dna.cbiot.ufrgs.br helpful in the optimization of current vaccines or in the design of novel ones.

Salivary molecules are well-known modulators of host immune systems and haemostasis, and are considered essential for the maintenance of parasite survival in the tick-mammalian relationship (Ribeiro, 1989, 1995; Wikel, 1999). Blockage of these immunomodulatory molecules appears promising for tick control. However, the analysis of such molecules is confounded by the small amounts of saliva that are available from ticks, which often makes their isolation and further characterization unfeasible. The identification of tick salivary cDNAs and the production of recombinant proteins is a more tractable alternative.

We show in this article the molecular cloning, characterization, expression in a prokaryotic system, and the analyses of some activities of a salivary gland paramyosin of B. microplus (BmPRM). Paramyosins are muscle proteins found within a number of different invertebrates, including arthropods, molluscs, annelids, crustaceans, nematodes and echinoderms (Maroto et al. 1995). Paramyosin is also found as part of the tegument of Schistosoma mansoni (Matsumoto et al. 1988; Gobert, 1998), and is one of the most promising candidates as a vaccine against schistosomiasis (Kallina \& McMannus, 1997; Gobert, 1998). The possible roles of this protein within 
the tick and in the tick-bovine relationship are also discussed.

\section{MATERIALS AND METHODS}

\section{Ticks}

B. microplus ovipositing females, eggs and larvae (Porto Alegre strain) were maintained in an incubator at $28{ }^{\circ} \mathrm{C}$ and $85 \%$ relative humidity, and their parasitic life was completed by feeding on calves, housed in individual pens on slatted floors.

\section{Harvest of saliva}

Partially engorged adult female ticks were obtained by direct detachment from the calves, kept in a wet chamber and salivation was induced by injection of $5 \mu 1$ of $2 \%$ pilocarpine solution in phosphatebuffered saline, $\mathrm{pH} 7 \cdot 2$ (PBS; 0.01 м sodium phosphate, $0.15 \mathrm{M} \mathrm{NaCl}$ ). Saliva was then collected directly from tick mouthparts.

\section{Antigen preparation}

Fully and partially engorged female ticks were washed with PBS. The dorsal surface was dissected with a scalpel blade. Salivary glands, guts, ovaries and fat bodies were separated with fine-tipped forceps and washed in PBS. These materials were kept frozen at $-70{ }^{\circ} \mathrm{C}$ until use. The frozen tissues were thawed and protein extracts prepared according to Da Silva Vaz et al. (1994). Protein concentrations of the extracts were measured using the Bradford method (1976) with bovine serum albumin as standard.

\section{Antisera}

Antibodies against salivary gland extracts and the purified BmPRM recombinant protein (rBmPRM) were raised in rabbits.

\section{Synthesis and screening of the salivary glands $c D N A$ library}

A unidirectional cDNA library was synthesized from salivary gland poly $\mathrm{A}^{+} \mathrm{RNA}$ of partially engorged adult females using the UNIZAP ${ }^{\circledR}$ vector (Stratagene), according to the instructions of the manufacturer. Poly $\mathrm{A}^{+}$RNA was obtained using the Micro-Fast Track ${ }^{\mathrm{TM}}$ Kit (Invitrogen). Immunological screening was performed using serum from a rabbit immunized with $B$. microplus salivary glands extract, as previously described (Rosa de Lima et al. 2002).

\section{DNA sequencing and sequence analysis}

DNA sequencing of all cDNAs isolated was performed on an ABI-PRISM 377 automated DNA sequencer (PerkinElmer, Foster City, CA) at the Molecular Genetics Facility, Georgia, USA. The FASTA algorithm (Pearson \& Lipman, 1988) was used to analyse the nucleotide and deduce aminoacid sequence homologies with previously reported sequences within databases. Multiple alignment of paramyosin sequences was performed with CLUSTALW (Thompson et al. 1994). The locations of coiled-coil regions were predicted by the PAIRCOIL program (Berger et al. 1995).

\section{Construction of a plasmid over-expressing rBmPRM}

In order to allow the expression and purification of rBmPRM the coding region of the cloned cDNA (named Bmprm) was amplified by PCR and subcloned into the pGEX-4T3 vector (AmershamPharmacia). The upstream (CCCCCCGAATTCATGTCTAGCAGGAGCAGC) and downstream (TTTTCCCCCCGCGGCCGCTTAGAAGTTCTGGCTGGAC) primers included EcoRI and Not I restriction sites, respectively, which were used for ligation to the vector. Correct cloning was confirmed by sequencing, and the recombinant plasmid named pGEX-PRM.

\section{Protein expression and purification}

BmPRM expression was performed in the BL21 Escherichia coli strain. Lysogens of BL21/pGEXPRM were prepared after growth in Luria-Bertani medium. Recombinant protein expression was induced with IPTG $0.1 \mathrm{~mm}$. Cell pellets from $2000 \mathrm{ml}$ cultures were suspended in $20 \mathrm{ml}$ of PBS and frozen at $-70{ }^{\circ} \mathrm{C}$. Cells were thawed and disrupted in a French press. Triton X-100 was added to the supernatant to a final concentration of $1 \%$, and centrifuged for $15 \mathrm{~min} / 12000 \mathrm{~g}$. The protein purification was then performed by use of glutathioneSepharose 4B (Amersham-Pharmacia) affinity chromatography. The supernatant was loaded on the column that had been equilibrated and washed with buffer A $(140 \mathrm{~mm} \mathrm{NaCl}, 2.7 \mathrm{~mm} \mathrm{KCl}, 10 \mathrm{~mm}$ $\mathrm{Na}_{2} \mathrm{HPO}_{4}, 1.8 \mathrm{~mm} \mathrm{KH}_{2} \mathrm{PO}_{4}$ ), and the fusion protein was then incubated with thrombin overnight at $23.5{ }^{\circ} \mathrm{C}$. The GST portion and the remaining fusion protein in the column were eluted with buffer B $(50 \mathrm{~mm}$ Tris- $\mathrm{HCl}, 10 \mathrm{~mm}$ glutathione, $\mathrm{pH} 8 \cdot 0)$. Protein purity was monitored by $10 \%$ SDS-PAGE (Laemmli, 1970) stained with Coomassie Blue G250. GST was produced using the same protocol, from lysogens of BL21/pGEX-4T1 (AmershamPharmacia), with the exception that thrombin was not added and protein elution was performed directly with buffer B.

\section{Western blots and dot-blot analyses}

For Western blot analyses, samples were resuspended in buffer containing $2 \%$ SDS, $250 \mathrm{~mm}$ Tris, 
$\mathrm{pH} 6 \cdot 8,0.025 \%$ bromophenol blue, $5 \%$ glycerol, $10 \% \beta$-mercaptoethanol and $5 \mathrm{~m}$ urea, separated by SDS-PAGE and transferred to nitrocellulose at $70 \mathrm{~V}$ for $1 \mathrm{~h}$ at $4{ }^{\circ} \mathrm{C}$ in $12 \mathrm{~mm}$ carbonate buffer, $\mathrm{pH}$ $9 \cdot 9$ (Dunn, 1986). The nitrocellulose sheets were blocked with BLOTTO (5\% cow non-fat dry milkPBS) for $2 \mathrm{~h}$ at room temperature. Anti-rBmPRM serum diluted 1:2000 was incubated overnight at $4{ }^{\circ} \mathrm{C}$. Prior to incubation with the antigens, all sera were diluted in an $E$. coli BL21 strain lysate expressing the pGEX-4T3 vector and incubated for $3 \mathrm{~h}$ at room temperature to allow the absorption of anti-E. coli and anti-vector derived protein antibodies. Preparation of the $E$. coli BL21 strain lysate was performed according to Rott et al. (2000). After 3 washes with BLOTTO, anti-rabbit IgG antibodies conjugated to alkaline phosphatase (Sigma) or peroxidase (Sigma), diluted 1:5000 and 1:2000 in BLOTTO respectively, were incubated for $1 \mathrm{~h}$ at room temperature. The membranes were then washed and stained as described for alkaline phosphatase (Rosa de Lima et al. 2002) and peroxidase (Da Silva Vaz et al. 1998) conjugates. Molecular weight standards were purchased from Bio-Rad (High Range).

Dot-blot analysis was performed using $5 \mu \mathrm{g}$ of rBmPRM in each spot. Native protein was applied to the nitrocellulose membrane diluted in PBS while denatured protein was applied after $10 \mathrm{~min}$ of boiling, diluted in PBS plus SDS $0.5 \%$ and $\beta$ mercaptoethanol $5 \%$. Membranes were blocked with BLOTTO for $2 \mathrm{~h}$ at room temperature. AntiBmPRM serum diluted 1:2000 or non-infested bovine serum diluted $1: 20$ were incubated for $1.5 \mathrm{~h}$ at room temperature. Prior to incubation with the antigens, all sera were diluted in an E. coli BL21 strain lysate expressing the pGEX-4T3 vector and incubated for $3 \mathrm{~h}$ at room temperature to allow the absorption of anti-E. coli and anti-vector derived protein antibodies. Preparation of the E. coli BL21 strain lysate was performed according to the method described by Rott et al. (2000). After 3 washes with BLOTTO, anti-rabbit IgG or anti-bovine $\mathrm{IgG}$ antibodies conjugated to alkaline phosphatase (Sigma) diluted 1:5000 and 1:2000 in BLOTTO, respectively, were incubated for $1 \mathrm{~h}$ at room temperature. After 3 washes with $\mathrm{PBS}$ and once with development buffer ( $5 \mathrm{~mm} \mathrm{MgCl}_{2}, 100 \mathrm{~mm} \mathrm{NaCl}$, $100 \mathrm{~mm}$ Tris, pH 9.5), membranes were stained with 5-bromo-4-chloro-3-indolylphosphate (BCIP) and nitroblue tetrazolium (NBT).

\section{IgG purification}

A pool of bovine sera from non-infested cattle was dialysed with $20 \mathrm{~mm}$ sodium phosphate buffer, $\mathrm{pH}$ $8 \cdot 4$, and applied to a protein G-Sepharose column (Amersham-Pharmacia) equilibrated with the same buffer and eluted with $100 \mathrm{~mm}$ glycine- $\mathrm{HCl}$ buffer,
$\mathrm{pH} 2 \cdot 7$. The fractions containing IgG were dialysed against PBS.

\section{ELISA}

Microtitration plates were coated with $2 \cdot 5 \mu \mathrm{g}$ of BSA (Sigma), rBmPRM or GST per well in $20 \mathrm{~mm}$ carbonate buffer ( $\mathrm{pH} 9.6$ ) by overnight incubation at $4{ }^{\circ} \mathrm{C}$ in a wet chamber (Harlow \& Lane, 1988). They were washed 3 times in BLOTTO and blocked by additionally incubating for $1 \mathrm{~h}$ at $37^{\circ} \mathrm{C}$ with BLOTTO. Either purified bovine $\mathrm{IgG}$ or total bovine serum were diluted in BLOTTO and incubated for $1 \mathrm{~h}$ at $37^{\circ} \mathrm{C}$. Prior to incubation with the antigens, both bovine serum and purified IgG were also added to an $E$. coli lysate (same procedure used for the Western blots) to remove any cross-reacting antibodies to $E$. coli and vector-derived proteins. PBS was also incubated with the $E$. coli lysate and used as a negative control (no antibodies or serum were added). The plates were then washed with BLOTTO 3 times and incubated for $1 \mathrm{~h}$ at $37^{\circ} \mathrm{C}$ with a secondary antibody conjugated to peroxidase (antibovine IgG, Sigma, diluted 1:2000). After 3 washes with PBS, the chromogen and substrate were added (3.4 mg $o$-phenylenediamine, $5 \mu \mathrm{l}$ of $\mathrm{H}_{2} \mathrm{O}_{2}$ in $0 \cdot 1 \mathrm{M}$ citrate-phosphate buffer, $\mathrm{pH} 5.0$ ) and incubated for $15 \mathrm{~min}$ at room temperature in a dark room. The reactions were stopped with $12.5 \% \mathrm{H}_{2} \mathrm{SO}_{4}$ and the optical densities (OD) were determined at $492 \mathrm{~nm}$.

\section{Collagen binding}

Seventeen mg of collagen type I (Sigma) were washed initially with $\mathrm{PBS}-\mathrm{NaCl} 0.65 \mathrm{M}$ (PBS plus $\mathrm{NaCl}$ up to $0.65 \mathrm{M}$ ) and subsequently with $\mathrm{PBS}$, and then incubated overnight at $4{ }^{\circ} \mathrm{C}$ with $300 \mu \mathrm{g}$ of GST and $300 \mu \mathrm{g}$ of rBmPRM in PBS. Collagen was then washed successively with $\mathrm{PBS}, \mathrm{PBS}-\mathrm{NaCl}$ $0.2 \mathrm{M}$ (PBS plus $\mathrm{NaCl}$ up to $0.2 \mathrm{M}$ ), $\mathrm{PBS}-\mathrm{NaCl}$ $0.25 \mathrm{M}$ (PBS plus $\mathrm{NaCl}$ up to $0.25 \mathrm{M}$ ) and $\mathrm{PBS}-\mathrm{NaCl}$ $0.3 \mathrm{M}$ (PBS plus $\mathrm{NaCl}$ up to $0.3 \mathrm{M}$ ). Elution was performed with $\mathrm{PBS}-\mathrm{NaCl} 0.65 \mathrm{M}$. All fractions were then concentrated and ionic strength was adjusted to physiological conditions using an Amicon microconcentrator filter (pore exclusion of 30000).

\section{RESULTS}

\section{Isolation and sequence analysis of BmPRM}

A single paramyosin-like cDNA clone (BmPRM) was obtained from 9000 cDNA clones by immunological screening from a salivary gland expression library. An antiserum raised in a rabbit against partially engorged salivary glands was used as a probe. The BmPRM sequence encodes a 2922 cDNA fragment with an open reading frame of 873 amino acids having high similarity to full-length paramyosin sequences (Fig. 1). The first initiation codon fulfills the criteria of Kozak for a ribosomal binding site 


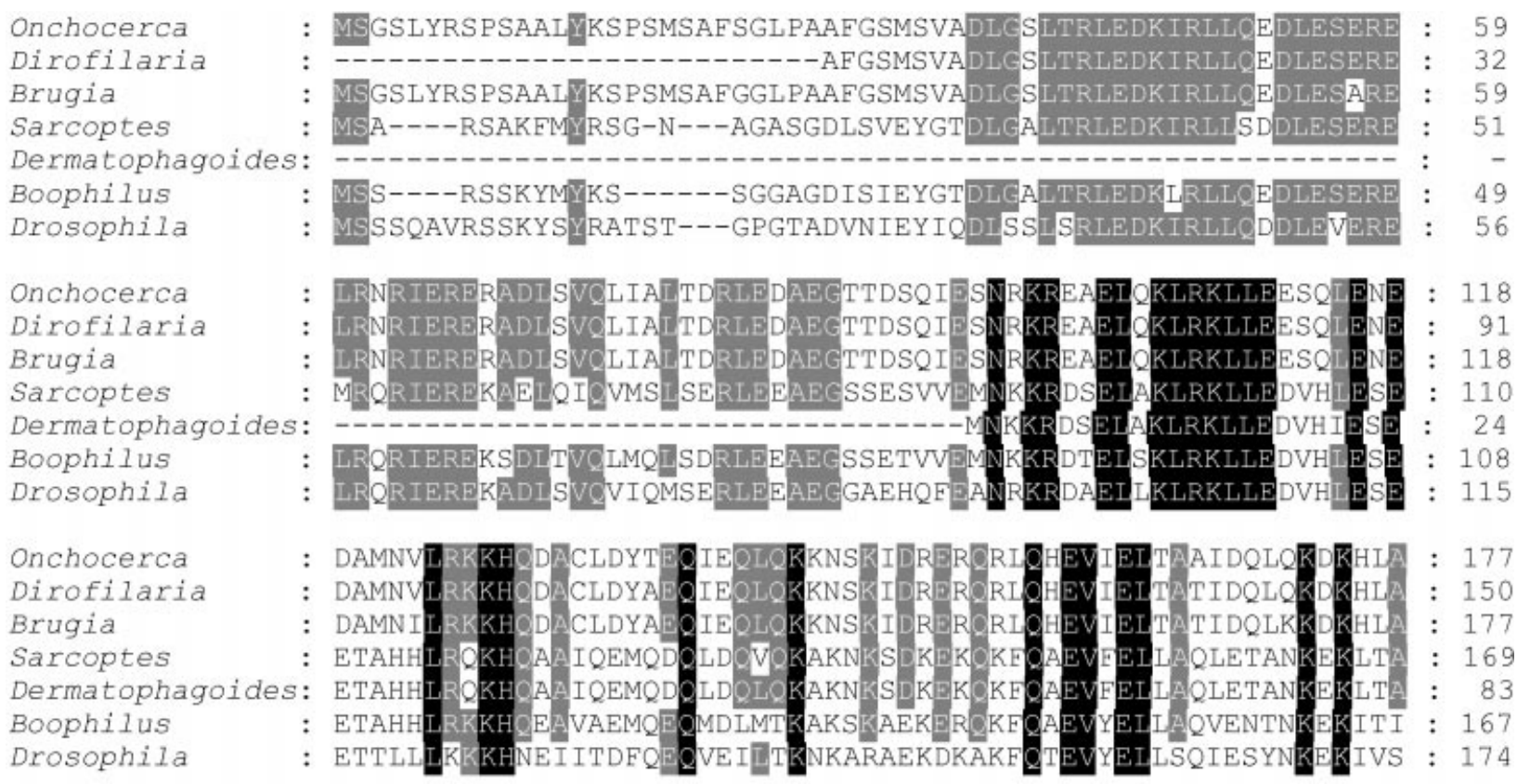

Onchocerca
Dirofilaria
Brugia
Sarcoptes
Dermatophagoides:
Boophilus
Drosophila

$\begin{array}{lr}\text { Onchocerca } & : \\ \text { Dirofilaria } & : \\ \text { Brugia } & : \\ \text { Sarcoptes } & \text { : } \\ \text { Dermatophagoides: } \\ \text { Doophilus }\end{array}$
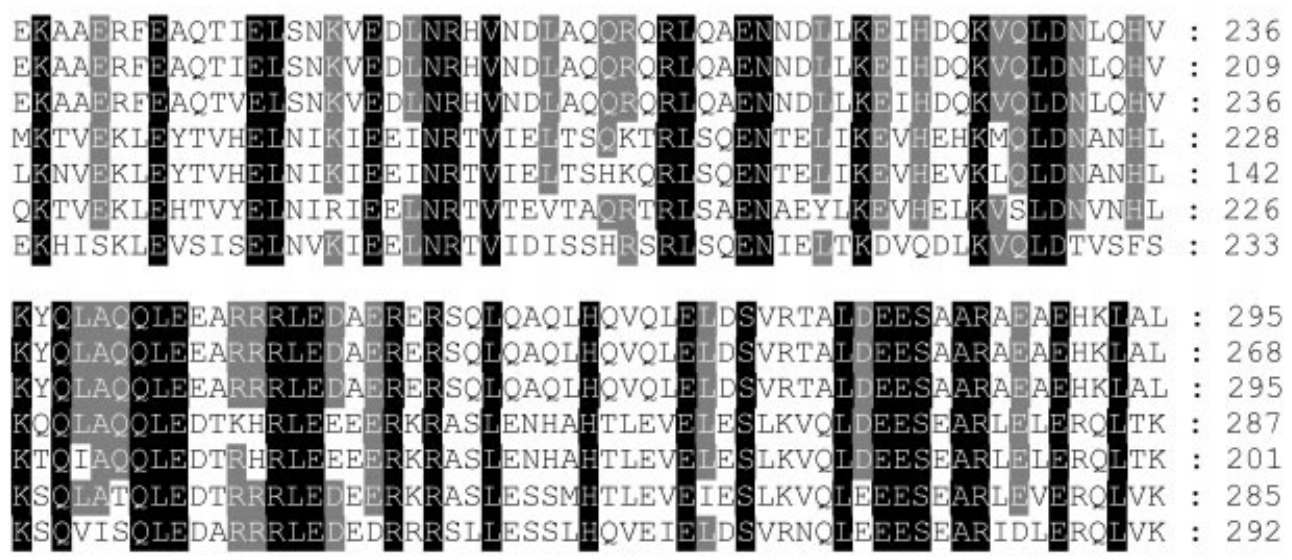

$\begin{array}{lr}\text { Onchocerca } & : \\ \text { Dirofilaria } & : \\ \text { Brugia } & : \\ \text { Sarcoptes } & : \\ \text { Dermatophagoides: } \\ \text { Boophilus } \\ \text { Drosophila }\end{array}$

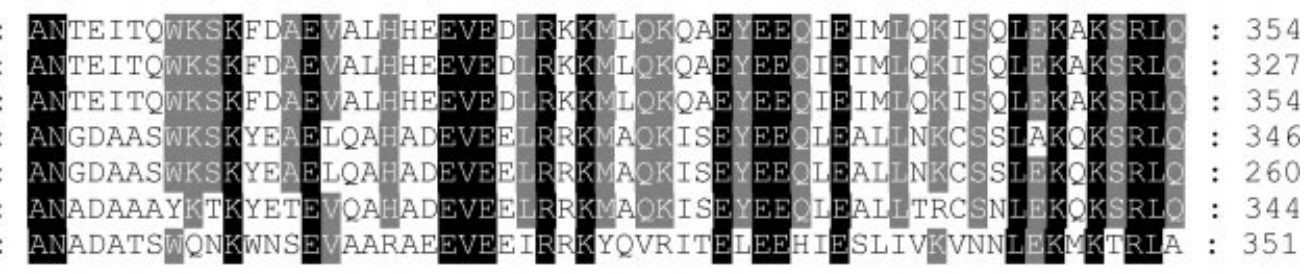

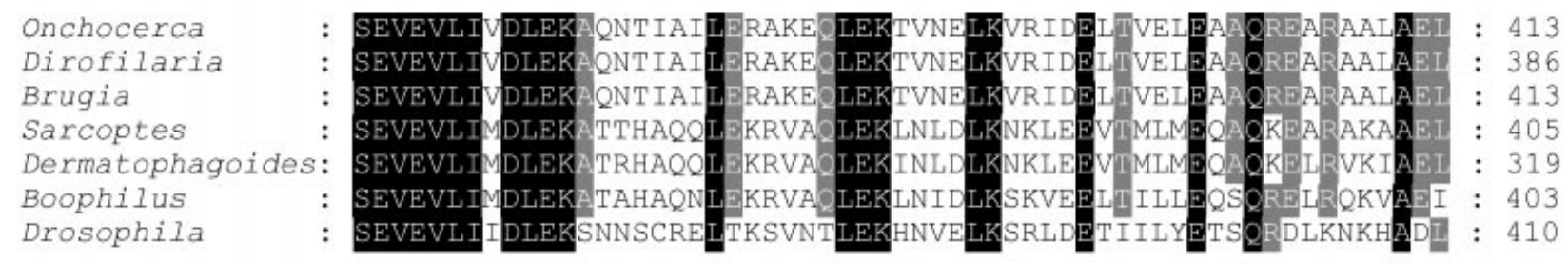

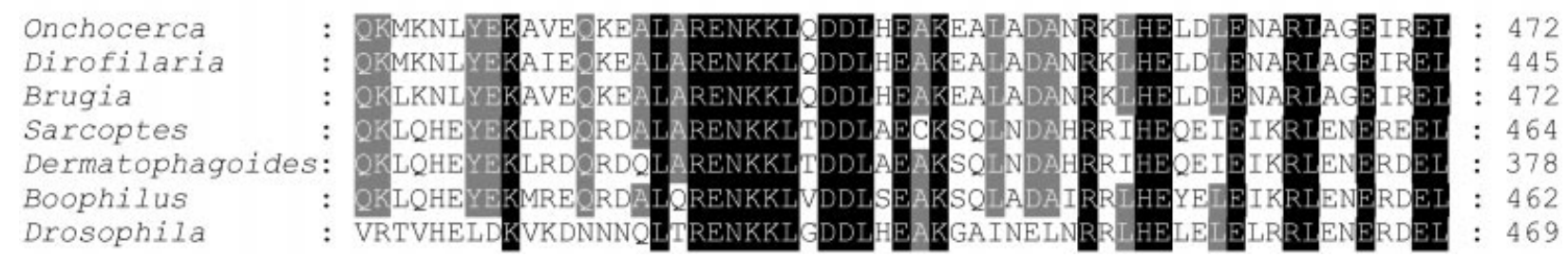

Fig. 1. For legend see facing page. 


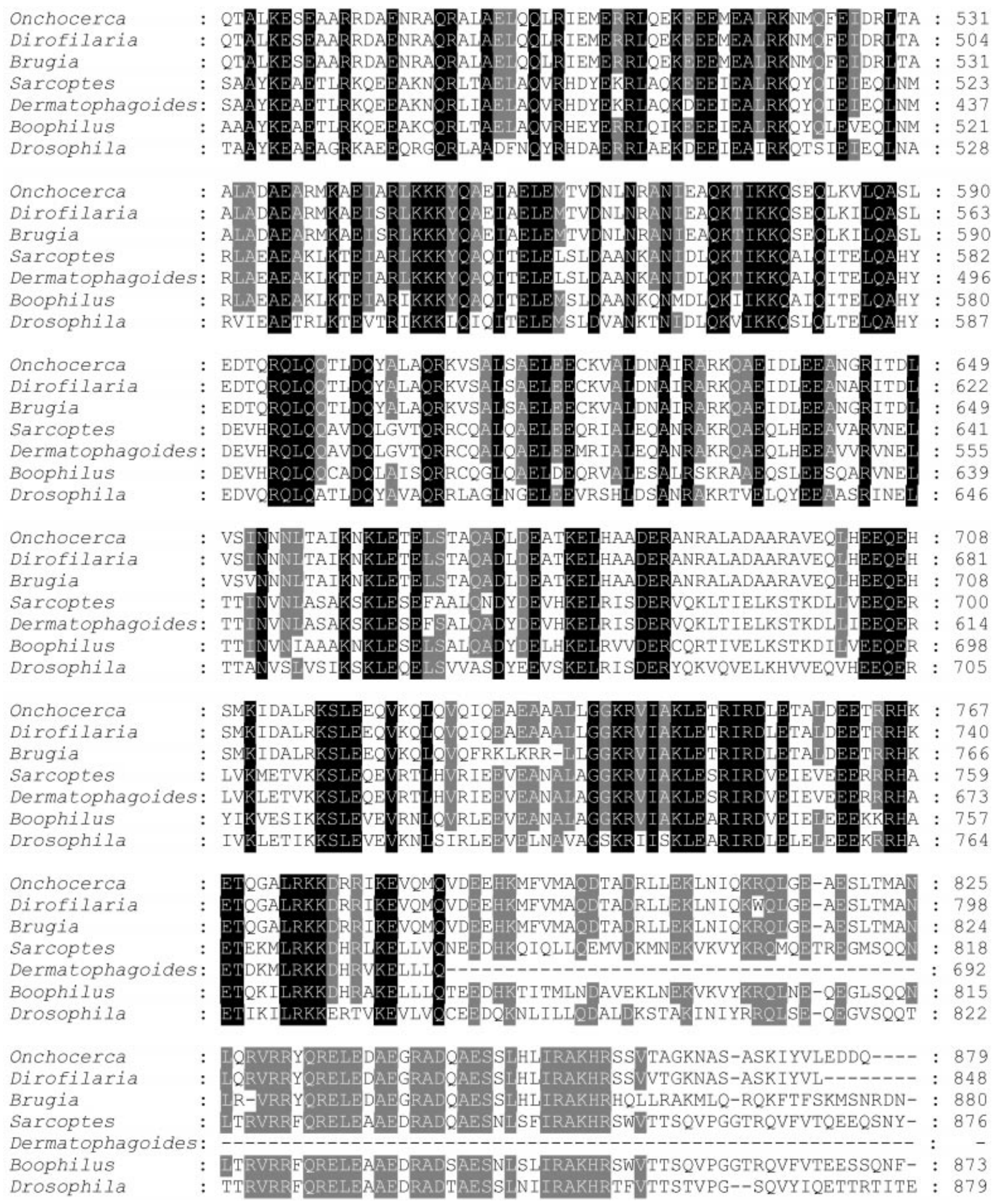

Fig. 1. Multiple alignment of the deduced amino acid sequence of BmPRM and other paramyosin sequences. Genbank accession numbers: Onchocerca volvulus, Q02171; Dirofilaria immitis, P13392; Brugia malayi, Q01202; Sarcoptes scabiei, Q9BMM8; Dermatophagoides farinae, AAK39511; Boophilus microplus (BmPRM), AF479582; Drosophila melanogaster, P35415. Dark shading shows identity and light shading shows residues conserved in $5 / 6$ sequences.

(Kozak, 1991). A 36 base pair (bp) $5^{\prime}$ and a 264 bp $3^{\prime}$ untranslated sequence are present, with a putative polyadenylationsignalpositioned 24 bpfromthepoly-A tail at the $3^{\prime}$ end. The predicted molecular mass and $\mathrm{pI}$ for $\mathrm{BmPRM}$ are $102 \mathrm{kDa}$ and 5.53 , respectively. Three putative $N$-glycosylation sites are present at residues $189-192,815-818$ and 839-842, and 2 leucine zipper motifs are present at residues 


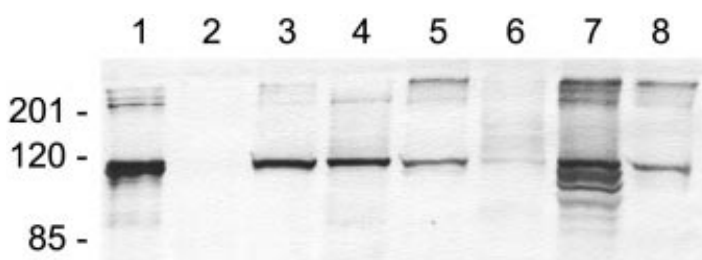

$47-$

Fig. 2. Western blot analysis of Boophilus microplus tissues, saliva and purified rBmPRM. Anti-rBmPRM rabbit serum diluted $1: 2000$. Lane 1 , purified rBmPRM $(1 \mu \mathrm{g})$; lane 2 , saliva from partially engorged females $(6 \mu \mathrm{g})$; lane 3 , partially engorged female salivary glands extract $(36 \mu \mathrm{g})$; lane 4 , fully engorged female fat body extract $(20 \mu \mathrm{g})$; lane 5 , partially engorged female gut extract $(18 \mu \mathrm{g})$; lane 6 , larval extract (96 $\mu \mathrm{g})$; lane 7 , non-engorged total adult female extract $(14 \mu \mathrm{g})$; lane 8 , total adult male extract $(49 \mu \mathrm{g})$. Molecular weight standards, kDa.
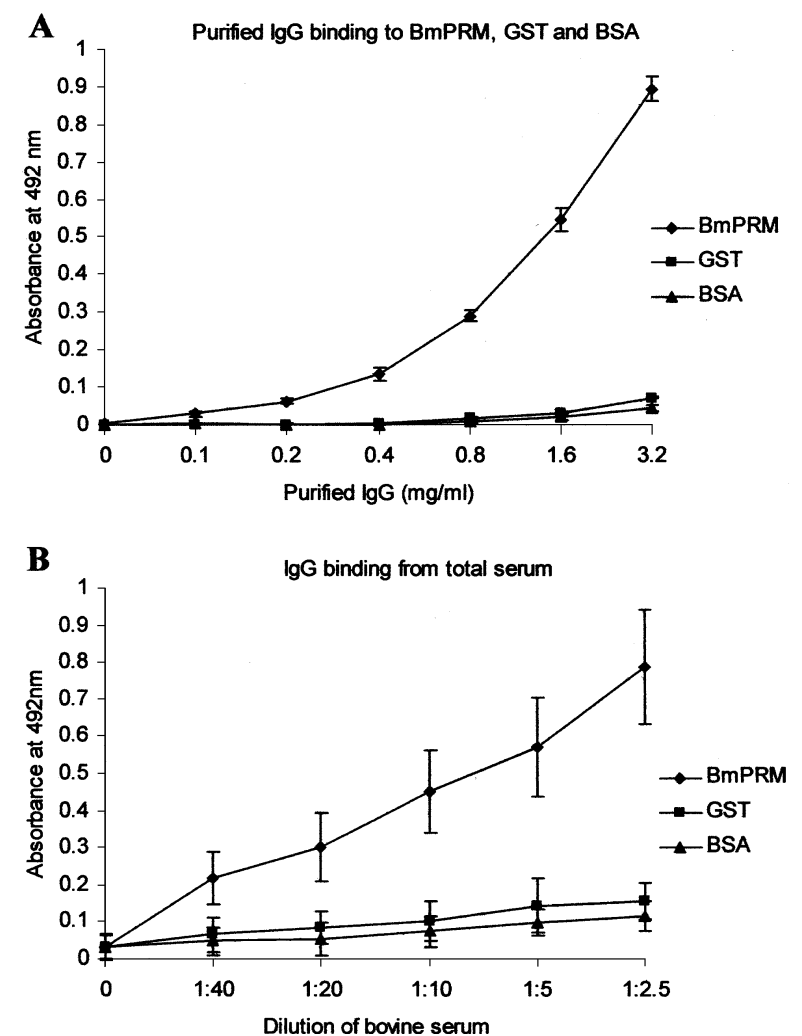

Fig. 3. IgG binding to rBmPRM detected by ELISA. Microplate wells were coated with $2.5 \mu \mathrm{g}$ of $\mathrm{rBmPRM}$, GST and BSA and incubated with doubling dilutions of purified IgG (from $0 \cdot 1$ to $3 \cdot 2 \mathrm{mg} / \mathrm{ml}$ in (A) or bovine sera (from $1: 2 \cdot 5$ to $1: 40$ in (B)). (A) Data are expressed as means \pm S.D. of triplicate experiments; (B) data are expressed as means \pm s.D. of 3 separate experiments, each one performed in duplicate, using different non-infested bovine sera. All sera and purified IgG were preabsorbed against $E$. coli extract prior to incubation with the proteins.
329-350 and 364-385. Several putative phosphorylation sites can also be deduced within the amino acid sequence of BmPRM. A coiled-coil-like secondary structure is predicted for most of the BmPRM sequence, with the exceptions covering the first 26 and the last 27 amino acids. The sequence data have been deposited in GenBank accession number AF479582.

Sequence alignment of BmPRM and 6 other paramyosin sequences shows that BmPRM shares the high conservation observed among paramyosins, especially within arthropods (Fig. 1). BmPRM shares $78 \%, 62 \%$ and $60 \%$ identity with Sarcoptes scabiei, Dermatophagoides farinae and Drosophila melanogaster, respectively (data not shown). The identities shared with the parasite nematodes Onchocerca volvulus, Dirofilaria immitis and Brugia malayi are less, being $52 \%, 52 \%$ and $51 \%$, respectively (data not shown), but are representative of the evolutionary conservation of paramyosins even among phylogenetically distant species.

\section{Subcloning and recombinant protein expression of BmPRM}

The full coding sequence of BmPRM was amplified by PCR and subcloned into the pGEX-4T3 vector (Amersham-Pharmacia), and then expressed in $E$. coli. rBmPRM, cleaved out from the fusion protein, was used to raise a hyperimmune serum on a rabbit. A high titre hyperimmune serum was also obtained when a bovine was immunized (data not shown).

\section{Identification of BmPRM within tick tissues and developmental stages}

The anti-rBmPRM serum was used in Western blot analysis of tick tissues/developmental stages (Fig. 2). The predicted band corresponding to BmPRM $(99-105 \mathrm{kDa})$ was present in all samples tested, with the exception of saliva. A 10-fold greater quantity of saliva was also tested, but the same result was obtained (data not shown). The presence of BmPRM in all tick tissues and developmental stages indicates ubiquitous expression of the BmPRM gene in $B$. microplus whereas the absence of BmPRM in saliva suggests that it is not secreted into the host while feeding. No bands were developed using preimmune serum (data not shown).

\section{Binding of bovine $\operatorname{Ig} G$ to $r B m P R M$}

Binding of rBmPRM to bovine IgG was demonstrated by ELISA. rBmPRM, GST (from Schistosoma japonicum, used as a fusion protein in the rBmPRM expression; see Materials and Methods section) and BSA were coated onto microplate wells and tested for binding to purified bovine IgG (Fig. 


\section{N \\ Bovine Serum}

\section{Anti-rBmPRM Serum}

Fig. 4. Dot-blot analysis of $\operatorname{IgG}$ binding activity of rBmPRM, (N) before and (D) after denaturation. The same amount of rBmPRM was applied to nitrocellulose membranes and incubated with non-infested bovine serum diluted $1: 20$. As a control a replicate was incubated with anti-rBmPRM rabbit serum diluted 1: 2000. Both sera were pre-absorbed against $E$. coli extract prior to incubation with the membranes.

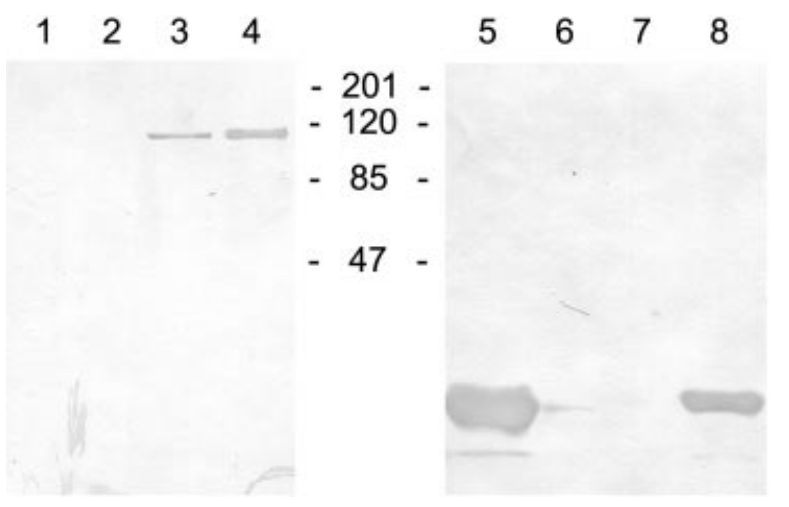

Fig. 5. rBmPRM binds collagen. rBmPRM and GST were incubated with type I collagen and fractions collected following stepwise salt washes. Anti-rBmPRM rabbit serum diluted 1:2000 was used as probe in lanes 1-4 and anti-GST monoclonal antibody diluted $1: 3000$ in lanes 5-8. Lanes 1 and 5, unbound protein; lanes 2 and 6 , last wash fraction $(0 \cdot 3 \mathrm{M} \mathrm{NaCl})$; lanes 3 and 7 , eluted protein; lanes 4 and 8 , purified rBmPRM $(4 \mu \mathrm{g})$ and GST $(4 \mu \mathrm{g})$. Molecular weight standards, kDa.

3A). rBmPRM showed dose-dependent binding over a $0 \cdot 1-3 \cdot 2 \mathrm{mg} / \mathrm{ml}$ concentration range, whereas GST and BSA did not show significant binding. In order to test if rBmPRM could also bind IgG of whole serum, we tested 3 different bovine sera (from noninfested animals) at 5 dilutions (Fig. 3B). Essentially the same results were obtained when whole sera were used. A dot-blot analysis was performed to compare the relative IgG-binding activity of native and denatured rBmPRM (Fig. 4). The IgG-binding activity was dramatically reduced using the denatured form, suggesting that binding is dependent on conformation.

\section{rBmPRM binding to collagen}

Collagen affinity of rBmPRM was tested by incubating the protein with type I collagen under physio- logical ionic strength conditions, followed by stepwise washes with increasing salt concentrations (up to $0.3 \mathrm{M} \mathrm{NaCl}$ ). Elution was achieved with a $0.65 \mathrm{M} \mathrm{NaCl}$ solution. GST was co-incubated with rBmPRM as a negative control. Fractions were concentrated, separated by SDS-PAGE and analysed by Western blot (Fig. 5). Detection of rBmPRM exclusively in the eluted fraction indicates binding to collagen and that most of the recombinant protein produced retains the binding capacity.

\section{DISCUSSION}

In this report we show the isolation, characterization and expression of a full length $B$. microplus $\mathrm{cDNA}$ sequence that encodes a $102 \mathrm{kDa}$ protein. The deduced sequence of BmPRM shows high similarity with full length paramyosin sequences from other organisms. Sequence and structural analyses indicate that BmPRM represents a paramyosin, a protein that has been described in several invertebrates (Kagawa et al. 1989; Maroto et al. 1995; Tsai et al. 1998; Mattson, Ljunggren \& Bergstrom, 2001). The predicted molecular weight of BmPRM lies within the values found for most paramyosins (Maroto et al. 1995). The predicted coiled-coil-like secondary structure is consistent with a rod-like shape, which is characteristic of paramyosins and myosin heavy chains (McLachlan \& Karn, 1982; Kagawa et al. 1989). Multiple alignment reveals a high degree of conservation between paramyosins and BmPRM. Furthermore, no gaps are present within the predicted $\alpha$-helical coiled-coil region (Fig. 1), suggesting that this portion is essential to protein function. This is demonstrated by the fact that point mutations in the Caenorhabditis elegans paramyosin within this region caused alterations in muscle structure and function (Gengyo-Ando \& Kagawa, 1991).

Paramyosin is found in the musculature of a large number of invertebrates (Maroto et al. 1995). It is also found in the tegument of $S$. mansoni (Matsumoto et al. 1988; Gobert, 1998), extending the possible functions of this protein. Exposure of paramyosin to the host offers the potential for paramyosin-based vaccines (Kalinna \& McManus, 1997). Also, muscle proteins were described as protective immunogens against the stable fly Stomoxys calcitrans (Schlein \& Lewis, 1976), which indicates that direct damage to muscle derived from an immunological response may occur. Differential tissue expression of paramyosin has been studied in D. melanogaster (Maroto et al. 1995; Arredondo et al. 2001). To our knowledge, other studies on the distribution of paramyosin in tissues and different development stages of arthropods have not been reported. Expression analysis of BmPRM clearly indicates that tick organs with no prominent musculature, like the fat body and salivary glands, give a strong signal 
for paramyosin. The apparent absence of BmPRM in the saliva is not unexpected, since BmPRM does not possess a signal sequence.

Paramyosin of Taenia crassiceps (Kalinna \& McManus, 1993), S. japonicum and S. mansoni (Loukas et al. 2001) have been shown to bind $\mathrm{IgG}$ non-immunologically. Schistosomes mask their surface with host proteins, including immunoglobulins (Tarleton \& Kemp, 1981); paramyosin is probably involved in this mechanism by acting as an $\mathrm{Fc}$ receptor on the parasites' surface (Loukas et al. 2001). This role of surface paramyosin partially explains the origin of host protection following immunization with the protein, as specific anti-paramyosin antiserum interferes with IgG binding both in vitro and in the tegument of living schistosome parasites (Loukas et al. 2001). We have demonstrated comparable activity with $\mathrm{rBmPRM}$, which binds both purified $\mathrm{IgG}$ and $\mathrm{IgG}$ present in intact serum, and is dependent on protein conformation. However, further studies are needed to determine whether BmPRM acts as an Fc receptor. If BmPRM does not make contact with the host immune system, it cannot be a potential target for vaccine development. However, tick immunoglobulin binding proteins have been described (Wang \& Nuttall, 1994, 1995), and a mechanism of selective $\mathrm{IgG}$ removal and excretion via salivation has been proposed (Wang \& Nuttall, 1995). In this model, specific proteins would be responsible for sequestering and transporting IgG to the salivary glands, via haemolymph. As discussed by Wang \& Nuttall (1999), such a mechanism could represent a self-defence system. IgGs would be delivered back into the host, possibly competing for the $\mathrm{Fc}$ receptors of cells like mast cells and basophils, which are thought to be essential for tick rejection by the host (Brown \& Askenase, 1985; Worms, Askenase \& Brown, 1988; Wang \& Nuttall, 1999). BmPRM did not show significant similarity to tick immunoglobulin binding proteins when compared within sequence databases (data not shown). Whether BmPRM functions as a physiological defence mechanism remains to be determined.

Another characteristic of native and recombinant paramyosins of many species is its ability to bind collagen (Laclette et al. 1990, 1992; Landa et al. 1993). This activity is especially important considering that paramyosin inhibits the classical pathway of the complement system, possibly by binding to the collagen-like stalks of Clq (Laclette et al. 1992). rBmPRM binds collagen, which suggests that BmPRM may also be a complement inhibitor. In addition, the presence of BmPRM in the gut may indicate its possible exposure to the bloodmeal, and consequently to the complement system. Specific uptake of immunoglobulins from the gut into the tick Amblyomma americanum haemolymph has been described, and the probable involvement of $\mathrm{IgG}$ binding proteins in the process has been suggested
(Jasinska, Jaworski \& Barbour, 2000). BmPRM could, in this situation, perform two distinct functions related to host immune system evasion.

The potential of paramyosin as a vaccine candidate against schistosomiasis has been demonstrated (Pearce et al. 1988; McManus et al. 1998, 2002; Chen et al. 2000; Zhou et al. 2000), and the IgG and collagen binding activities described in the paramyosins of worms and molluscs (Laclette et al. 1992; Loukas et al. 2001), which are the likely ultimate targets of the immunological attack, were shown to be conserved in arthropods, or at least in rBmPRM. The use of immunoglobulin binding proteins as immunogens in anti-tick vaccines has been proposed, and an experiment using a recombinant IgG binding protein in guinea-pigs resulted in a prolongation of the engorgement time required by female Rhipicephalus appendiculatus (Wang \& Nuttall, 1999). Although BmPRM is not apparently in contact with the host immune system, its presence in several organs and developmental stages of the tick deserves greater attention. It may reflect the importance of BmPRM in functions related to host immune system evasion and, as such, provide a target for immunoprophylatic intervention, as a new 'concealed' antigen.

We are grateful to Dr Carlos Termignoni, Dr Fabiana Horn and Mozart da Silva Lauxen for helpful discussions and critical reading of the manuscript, and to Dr José Marcos C. Ribeiro for important cooperation. We wish to thank Cenbiot for the supply of restriction enzymes. This work was supported by grants from CAPES, CNPq, PRONEX, PADCT and FAPERGS.

\section{REFERENCES}

ARREDONdo, J. J., FERRERES, R. M., MAROTO, M., CRIPPS, R. M., MARCo, R., BERnstein, S. I. \& CERVERA, M. (2001). Control of Drosophila paramyosin/miniparamyosin gene expression. Fournal of Biological Chemistry 276, 8278-8287.

BERGER, B., Wilson, D. B., WOlF, E., TONCHEV, T., Milla, M. \& KIM, P. S. (1995). Predicting coiled coils by use of pairwise residue correlations. Proceedings of the National Academy of Sciences, USA 92, 8259-8263. BRADFORD, M. M. (1976). A rapid and sensitive method for the quantitation of microgram quantities of proteins utilizing the principle of protein-dye binding. Analytical Biochemistry 72, 248-254.

Brown, s. J. \& ASkenase, P. W. (1985). Amblyomma americanum: requirement for host $\mathrm{Fc}$ receptors in antibody mediated acquired immune resistance to ticks. Experimental Parasitology 59, 248-256.

CHEN, H., NARA, T., ZENG, X., SATOH, M., WU, G., JIANG, W., Yi, F., KOJIMA, S., ZHANG, S. \& HiRAYAMA, K. (2000). Vaccination of domestic pig with recombinant paramyosin against Schistosoma japonicum in China. Vaccine 18, 2142-2146.

DA SIlva VAZ, I., JR. OZAKI, L. S. \& MASUdA, A. (1994). Serum of Boophilus microplus infested cattle reacts with different tick tissues. Veterinary Parasitology 52, $71-78$. 
DA Silva VAZ, I., JR. LOGUllo, C., SORGine, M., VElloso, F. F., ROSA DE LIMA, M. F., GONZALES, J. C., MASUdA, H., OLIVEIRA, P. L. \& MASUDA, A. (1998). Immunization of bovines with an aspartic proteinase precursor isolated from Boophilus microplus eggs. Veterinary Immunology and Immunopathology 66, 331-341.

DUNN, s. D. (1986). Effects of the modification of transfer buffer composition and the renaturation of proteins in gels on the recognition of proteins on Western-blot by monoclonal antibodies. Analytical Biochemistry 157, 144-153.

GARCiA-Garcia, J. C., MONTERo, C., REdondo, M., VARGas, M., Canales, M., Boue, O., Rodriguez, M., Joglar, M., MACHAdo, H., GONZALEZ, I. L., VAldes, M., MENDEZ, L. \& DE LA FUENTE, J. (2000). Control of ticks resistant to immunization with $\mathrm{Bm} 86$ in cattle vaccinated with the recombinant antigen $\mathrm{Bm} 95$ isolated from the cattle tick, Boophilus microplus. Vaccine 18, 2275-2287.

GENGYO-ANDO, K. \& KAGAWA, H. (1991). Single charge change on the helical surface of the paramyosin rod dramatically disrupts thick filament assembly in Caenorhabditis elegans. Fournal of Molecular Biology 219, 429-441.

GOBERT, G. N. (1998). The role of microscopy in the investigation of paramyosin as a vaccine candidate against Schistosoma japonicum. Parasitology Today 14, 115-118.

HARlow, E. \& LANE, D. (1988). Antibodies : a Laboratory Manual. Cold Spring Harbor Laboratory Press, Cold Spring Harbor, New York.

JASinska, A., JAWORSKi, D. C. \& BARBouR, A. G. (2000). Amblyomma americanum: specific uptake of immunoglobulins into tick hemolymph during feeding. Experimental Parasitology 96, 213-221.

KagaWA, H., GENGyo, K., MclaChlan, A. D., BRENNER, S. \& KARN, J. (1989). Paramyosin gene (unc-15) of Caenorhabditis elegans: molecular cloning, nucleotide sequence and models for thick filament structure. Fournal of Molecular Biology 207, 311-333.

KAlinna, B. H. \& McManus, D. P. (1993). An IgG (Fc $)$ binding protein of Taenia crassiceps (Cestoda) exhibits sequence homology and antigenic similarity with schistosome paramyosin. Parasitology 106, 289-296.

KAlinNA, B. H. \& McMANUS, D. P. (1997). A vaccine against the asian schistosome, Schistosoma japonicum: an update on paramyosin as a target of protective immunity. International Fournal of Parasitology 27, 1213-11219.

KOZAK, M. (1991). An analysis of vertebrate mRNA sequences: intimations of translational control. Fournal of Cell Biology 115, 887-903.

LaClette, J. P., Alagón, A., Willms, K. \& TORRE-Blanco, A. (1990). Purification of antigen B from Taenia solium cysticerci by affinity to collagen. Fournal of Parasitology 76, 273-275.

LAClette, J. P., ShOemaker, C. B., Richter, D., ARCos, L., PANTE, N., COHEN, C., BING, D. \& NICHOLSON-WELlER, A. (1992). Paramyosin inhibits complement C1. Fournal of Immunology 148, 124-128.

LAEMMLI, U. K. (1970). Cleavage of structural proteins during assembly of the head of bacteriophage $\mathrm{T} 4$. Nature, London 227, 680-685.

LANDA, A., LACletTe, J. P., NICHOLSON-WELlER, A. \& SHOEMAKER, C. B. (1993). cDNA cloning and recombinant expression of collagen-binding and complement inhibitor activity of Taenia solium paramyosin (AgB). Molecular and Biochemical Parasitology 60, 343-348.

LOUKAS, A., JONES, M. K., KING, L. T., BRINDLEY, P. J. \& McManus, D. P. (2001). Receptor for Fc on the surfaces of schistosomes. Infection and Immunity 69 , 3646-3651.

MARoto, M., ARREDONDO, J. J., SAN ROMAN, M., MARCO, R. \& CERVERA, M. (1995). Analysis of the paramyosin/miniparamyosin gene. Fournal of Biological Chemistry 270, 4375-4382.

Mclachlan, A. D. \& KARN, J. (1982). Periodic charge distributions in the myosin rod amino acid sequence match cross-bridge spacings in muscle. Nature, London 229, 226-231.

McManus, D. P., LIU, S., SONG, G., XU, Y. \& WONG, J. M. (1998). The vaccine efficacy of native paramyosin (Sj-97) against chinese Schistosoma japonicum. International Fournal for Parasitology 28, 1739-1742.

McMANUS, D. P., WONG, J. Y. M., ZHOU, J., CAI, C., ZENG, Q., SMYTH, D., LI, Y., KALINNA, B. H., DUKE, M. J. \& YI, X. (2002). Recombinant paramyosin (rec-Sj-97) tested for immunogenicity and vaccine efficacy against Schistosoma japonicum in mice and water buffaloes. Vaccine 20, 870-878.

Matsumoto, Y., Perry, G., LeVine, R. J. C., Blanton, R., MAHMoUd, A. A. F. \& AIKAWA, M. (1988). Paramyosin and actin in schistosomal teguments. Nature, London 333, 76-78.

Mattson, J. G., LJungGren, E. L. \& Bergstrom, K. (2001). Paramyosin from the parasitic mite Sarcoptes scabiei: cDNA cloning and heterologous expression.

Parasitology 122, 555-562.

mulenga, A., Sugimoto, C. \& onuma, M. (2000). Issues in tick vaccine development: identification of potential candidate vaccine antigens. Microbes and Infection 2 , 1353-1361.

NOLAN, J. (1985). Mechanisms of resistance to chemicals in arthropod parasites of veterinary importance. Veterinary Parasitology 18, 155-166.

PEARCE, E. J., JAMES, S. L., HIENY, S., LANAR, D. E. \& SHEER, A. (1988). Induction of protective immunity against Schistosoma mansoni by vaccination with schistosome paramyosin (Sm97), a nonsurface parasite antigen. Proceedings of the National Academy of Sciences, USA 85, 5678-5682.

PEARSON, W. R. \& LIPMAN, D. J. (1988). Improved tools for biological sequence comparison. Proceedings of the National Academy of Sciences, USA 85, 2444-2448. RIBEIRo, J. M. C. (1989). Role of saliva in tick/host interactions. Experimental and Applied Acarology 7, 15-20.

RIBEIRo, J. M. C. (1995). How ticks make a living. Parasitology Today 11, 91-93.

Rodriguez, M., PENiChet, M. L., MOURis, A. E., LABARTA, V., LORENZO LUACES, L., RUBIERA, R., CORDOVÉS, C., SÁNCHEZ, P. A., RAMOS, E., SOTO, A., CANALES, M., PAlENZUEla, D., TRIGUERO, A., LleONARD, R., HERRERA, L. \& DE LA Fuente, J. (1995 a). Control of Boophilus microplus populations in grazing cattle vaccinated with a recombinant Bm86 antigen preparation. Veterinary Parasitology 57, 339-349. 
RODRIGUEZ, M., MASSARD, C. L., FONSECA, A. H., RAMOS, N. F., MACHADO, H., LABARTA, V. \& DE LA FUENTE, J. $(1995 b)$. Effect of vaccination with a recombinant Bm86 antigen preparation on natural infestations of Boophilus microplus in grazing dairy and beef pure and cross-bred cattle in Brazil. Vaccine 13, 1804-1808.

ROSA DE LIMA, M., FERREIRA, C. A. S., FREITAS, D. R. J. \& MASUDA, A. (2002). Cloning and partial characterization of Boophilus microplus (Acari: Ixodidae) glutathione-S-transferase. Insect Biochemistry and Molecular Biology 32, 747-754.

ROTT, M. B., FERnándeZ, V., FARIAS, s., CENi, J., FERREIRA, H. B., HAAG, K. L. \& ZAHA, A. (2000). Comparative analysis of two different subunits of antigen B from Echinococcus granulosus: gene sequences, expression in Escherichia coli and serological evaluation. Acta Tropica 75, 331-340.

SCHLEIN, Y. \& LEWIS, C. T. (1976). Lesions in haematophagous flies after feeding on rabbits immunized with fly tissues. Physiological Entomology 1, 55-59.

TARLETON, R. L. \& KEMP, W. M. (1981). Demonstration of IgG-Fc and C3 receptors on adult Schistosoma mansoni. Fournal of Immunology 126, 379-384.

THompson, J. D., HigGins, D. G. \& Gibson, T. J. (1994).

CLUSTAL W: improving the sensitivity of progressive multiple sequence alignment through sequence weighting, position-specific gap penalties and weight matrix choice. Nucleic Acids Research 22, 4673-4680.

TSAI, L. C., CHAO, P. L., SHEN, H. D., TANG, R. B., CHANG, T. C., CHANG, Z. N., HUNG, M. W., LEE, B. L. \& CHUA,
K. L. (1998). Isolation and characterization of a novel 98-kd Dermatophagoides farinae mite allergen. Fournal of Allergy and Clinical Immunology 102, 295-303.

WANG, H. \& NUTTAll, P. A. (1994). Excretion of host immunoglobulin in tick saliva and detection of $\mathrm{IgG}$ binding proteins in tick haemolymph and salivary glands. Parasitology 109, 525-530.

WANG, H. \& NUTTall, P. A. (1995). Immunoglobulin-G binding proteins in the ixodid ticks, Rhipicephalus appendiculatus, Amblyomma variegatum and Ixodes hexagonus. Parasitology 111, 161-165.

WANG, H. \& NUTTALl, P. A. (1999). Immunoglobulinbinding proteins in ticks: new target for vaccine development against a blood-feeding parasite. Cellular and Molecular Life Sciences 56, 286-295.

Wikel, S. K. (1999). Modulation of the host immune system by ectoparasitic arthropods. BioScience 49, 311-320.

WILlADSEN, P., BIRD, P., COBON, G. S. \& HUNGERFORD, J. (1995). Commercialisation of a recombinant vaccine against Boophilus microplus. Parasitology 110, 843-850.

Willadsen, P. \& KEMP, D. H. (1988). Vaccination with 'concealed' antigens for tick control. Parasitology Today 4, 196-198.

WORMs, M. J., ASKENASE, P. W. \& BROWN, S. J. (1988). Requirement for host $\mathrm{Fc}$ receptors and $\mathrm{IgG}$ antibodies in host immune responses against Rhipicephalus appendiculatus. Veterinary Parasitology 28, 153-161. ZHOU, s., LIU, S., SONG, G., XU, Y. \& SUN, W. (2000). Protective immunity induced by the full-length cDNA encoding paramyosin of chinese Schistosoma japonicum. Vaccine 18, 3196-3204. 